\title{
Pengaruh Penerapan Pendekatan Saintifik Melalui Model Discovery Learning Terhadap Hasil Belajar IPA
}

\section{Linda Pratiwi}

SD Negeri Munggangsari

lindapratiwi1116@gmail.com

\section{Article History}

received 3/12/2020

\begin{abstract}
This research started with doubts whether the application of the scientific approach through the Discovery Learning model in science learning in elementary schools was appropriate. The research conducted is experimental research with the type of Quasi Experimental Design, while the research design used in this study is non equivalent control group design. Based on the results of the study, it can be seen from the analysis using the Independent Sample Test. From the results of the Independent Sample t-Test test for the Equal variance assumed column, it was obtained that the $t$-count coefficient was 2.672 with a significance value in the Sig (2-tailed) column of 0.01 . 87.7273 and for the control class of 80.88 with the average difference in learning outcomes is 6.8472 . These results indicate that there is a significant difference in influence between learning with a scientific approach through Discovery Learning and PBL in science subjects.
\end{abstract}

Keywords: scientific approach, discovery learning, science

\begin{abstract}
Abstrak
Penelitian ini berawal dari keraguan sesuaikah penerapan pendekatan saintifik melalui model Discovey Learning dalam pembelajaran IPA di sekolah dasar. Penelitian yang dilakukan adalah penelitian eksperimen dengan jenis Quasi Experimental Design, sedangkan desain penelitian yang digunakan dalam penelitian ini adalah Non Equivalent Control Group Design.. Berdasarkan hasil penelitian dilihat dari analisis menggunkan uji Independent Sample Test. Dari hasil uji Independent Sample t-Test kolom Equal variance assumed diperoleh bahwas koefisien t hitung sebesar 2,672 dengan nilai signifikansinya pada kolom Sig (2-tailed) sebesar 0,01 .Sedangkan dalam penelitian ini, untuk perolehan rata-rata hasil belajar kelas ekperimen sebesar 87,7273 dan untuk kelas control sebesar 80,88 dengan perbedaan rata-rata hasil belajaranya adalah 6,8472 . Hasil ini menunjukan bahwa terdapat perbedaan pengaruh yang signifikan antara pembelajaran dengan pendekatan saintifik melalui Discovery Learning dengan PBL mata pelajaran IPA.
\end{abstract}

Kata kunci: pendekatan saintifik, discovery learning, IPA

Social, Humanities, and Education Studies (SHEs): Conference Series https://jurnal.uns.ac.id/shes

p-ISSN 2620-9284

e-ISSN 2620-9292 


\section{PENDAHULUAN}

Perkembangan kurikulum bukan merupakan hal baru bagi dunia pendidikan di Indonesia. Sejak masa kemerdekaan tahun 1945 sampai dengan sekarang telah tercatat lebih dari delapan kali perubahan kurikulum, dimulai dengan Kurikulum Rencana Pelajaran 1947 yang terus disempurnakan sampai dengan Kurikulum 2013.Perubahan tersebut terjadi sebagai konsekuensi logis dari terjadinya perubahan sistem politik, sosial budaya, ekonomi, dan iptek dalam masyarakat berbangsa dan bernegara. Meskipun kurikulum selalu mengalami perubahan, pada dasarnya semua kurikulum nasional dirancang berdasarkan landasan yang sama, yaitu Pancasila dan UUD 1945.

Kurikulum yang terakhir kali mengalami perubahan dan diterapkan di beberapa sekolah pada tahun 2013 adalah kurikulum 2013. Kurikulum 2013 merupakan kurikulum yang diberlakukan untuk menyempurnakan kurikulum 2006. Meskipun demikian dalam implementasi kurikulum 2013 di beberapa sekolah di Indonesia masih mengalami banyak kendala. Hal tersebut sejalan dengan pernyataan Anies Baswedan (Kompas.com:2013) yang megungkapkan bahwa kendala-kendala yang dihadapi kurikulum 2013 meliputi masalah dalam kesiapan buku, sistem penilaian, penataran guru, pendamping guru dan pelatihan kepala sekolah yang belum merata.

Berdasarkan masalah yang ditemui dalam implementasi kurikulum 2013, pemerintah melalui permendikbud No. 61 tahun 2014 menetapkan berlakunya kembali kurikulum 2006. Meskipun demikian bukan berarti penerapan kurikulum 2013 tidak sesuai dengan tujuan pendidikan di Indonesia. Mengenai pelaksanaan implementasi kurikulum 2013, Hamid (kompasiana.com:2014) menyatakan bahwa ide dan konsep kurikulum 2013 sudah tepat karena hendak menyiapkan generasi bangsa dengan penekanan penguataan pendidikan karakter. Penguatan pendidikan karakter dalam pembelajaran terwujud melalui pendekatan saintifik kurikulum 2013.

Pendekatan saintifik merupakan pendekatan proses pembelajaran dimana lebih aktif mengkonstruksi pengetahuan dan keterampilannya dengan tahap-tahap ilmiah Daryanto (2014:51). Pendekatan Saintifik salah satu keunggulan kurikulum 2013. Affandi (kompasiana.com:2014) mengatakan sebagian guru lain justru senang bilamana memanfaatkan cara saintifik. Karena sesungguhnya cara ini lebih mementingkan siswa berbuat aktif. Guru menempatkan diri sebagai salah satu sumber belajar. Disamping itu, guru memang dituntut untuk mengelola kelas yang dituntut untuk aktif. Filosofinya: dari siswa,oleh siswa, untuk siswa

Lebih lanjut Fauzan (kompasiana.com:2014) menyatakan bahwa melalui pendekatan saintifik guru membelajarkan peserta didik sesuai zamannya berbingkai ilmu pengetahuan dan teknologi untuk menanamkan sikap disiplin, kreatif, inovatif, dan kompetitif." Melihat esensi pendekatan saintifik baik kiranya mulai diterapkan dari pendidikan dasar. Hal ini sesuai dengan Teori Perkembangan Kognitif Piaget (dalam Sudrajat (2014)) yang mengatakan bahwa mulai usia 11 tahun hingga dewasa (tahap formal-operasioanal), seorang individu telah memiliki kemampuan kognitif. Sehingga pembelajaran dengan pendekatan saintifik sangat mungkin diberikan mulai pada usia tahapan ini.

Dilain sisi Fauzan (kompasiana.com:2014) juga menguraikan kelemahan pendekatan saintifik bahwa program model pembelajaran guru untuk mengaplikasikan pendekatan saintifik kurikulum 2013 masih belum kokoh. Lebih lanjut Swastantika (kompasiana.com:2014) mengungkapkan langkah-langkah pembelajaran dalam pendekatan saintifik dianggap berat untuk diimplementasikan siswa sekolah dasar karena tingkat berfikirnya masih rendah.

Selain pendekatan saintifik kurikulum 2013 menawarkan model-model pembelajaran lain yang sesuai dengan karakteristik kurikulum 2013 yaitu discovery/inquiry learning, project based learning dan problem based learning seperti yang tertuang dalam Permendikbud No.65 Tahun 2013 tentang Standar Proses 
Pendidikan Dasar dan Menengah, bahwa untuk memperkuat pendekatan saintifik bisa diterapkan model pembelajaran berbasis penelitian discovery/inquiry learning, project based learning dan problem based learning." Meskipun masing- masing model pembelajaran tersebut mempunyai kelebihan dan kelemahan. Namun guru tidak perlu memperuncing kekurangan-kekurangan pada masing-masing model pembelajaran yang dimaksud. Lebih lanjut Herriaty (kompasiana.com:2014) menyatakan bahwa dalam mengajar guru perlu melakukan inovasi-inovasi dari tiga model pembelajaran tersebut sesuai dengan situasi dan kondisi sekolah dan kelas serta saranan prasarana yang ada.

Berdasarkan uraian yang telah disebutkan pendekatan saintifik salah satunya dapat diterapkan dengan model pembelajaran Discovery Learning. Sani (2014:97) mengatakan bahwa model Discovery Learning adalah menemukan konsep melalui serangkaian data atau informasi yang diperoleh melalui pengamatan atau percobaan. Di mana dalam pembelajarannya dapat mendorong siswa untuk melakukan penyelidikan guna menemukan kebenaran ilmiah, bukan diajak untuk beropini dalam melihat suatu fenomena. Mata pelajaran yang berbasis penyikapan ilmiah salah satu mata pelajaran IPA. Dari pernyatan tersebut, apakah benar model Discovery Learning diterapakan dalam mata pelajaran IPA mampu mendorong siswa melakukan sebuah penyelidikan untuk menemukan kebenaran ilmiah. Oleh karena itu hal ini menarik perhatian untuk dilakukan penelitian mengenai pengaruh pendekatan saintifik melalui model pembelajaran Discovery Learning pada mata pelajaran IPA. Adapun sebagai pembanding pada penelitian ini adalah model pembelajaran Problem Based Learning (PBL). Model Problem Based Learning merupakan model yang basisnya adalah masalah.

\section{METODE}

Jenis penelitian ini menggunakan penelitian ekperimen semu (Quasi Experimental Design). Desain penelitian yang digunakan dalam penelitian ini adalah Non Equivalent Control Group Design, dimana menurut Sugiono (2013:79) terdapat dua kelompok yang tidak dipilih secara random kemudian diberi pretest untuk mengetahui keadaan awal apakah terdapat perbedaan yang signifikan antara kelas ekperimen dan kelas control. Subjek dalam penelitian ini adalah siswa kelas 3 SD Negeri Munggangsari dengan jumlah siswa 22 dan siswa kelas 3 SD Negeri Kataan dengan jumlah siswa 25. Pada penelitian ini untuk pengumpulan data menggunakan observasi dan tes. Observasi dalam penilitian ini digunakan untuk mengamati tingkah laku guru kelas pada waktu mengajar dengan menerapkan pendekatan saintifik melalui model pembelajaran Discovery Learning ataupun pembelajaran PBL. Dalam penelitian ini pembelajaran dengan pendekatan saintifik melalui model Discovery Learning digunakan guru dalam pembelajaran kelas ekperimen. Dan model pembelajaan $P B L$ digunakan guru dalam kelas kontrol. Teknik tes digunakan untuk mendapat hasil dari mengerjakan soal IPA. Dalam penelitian ini tes digunakan untuk mengetahui sejauh mana keberhasilan proses belajar mengajar yang dilakukan pada akhir kegiatan pembelajaran. Teknik analisis data dalam penelitian ini yaitu dengan uji prasyarat, dan uji t. Dalam uji prasyarat ada dua uji yang dilakukan yaitu uji normalitas dan uji homogenitas.

\section{HASIL DAN PEMBAHASAN}

Sebelum penelitian dilaksanakan, kedua kelas penelitian telah diuji kesamaan varian yang menunjukan keadaan kedua kelas yang homogen. Artinya bahwa sebelum diberi perlakuan kedua kelas mempunyai kondisi dan kemampuan awal yang tidak berbeda secara signifikan sehingga kelas ekperimen dapat diberi treatment yaitu dengan pembelajaran pendekatan saintifik melalui model pembelajaran Discovery Learning dan kelas kontrol menggunakan pembelajaran model Problem Based 
Learning. Setelah diberi treatment pada kelas ekperimen dan kelas kontrol diberikan tes akhir (posttest) untuk mengukur hasil belajar IPA materi sumber energi dan kegunaannya. Pelaksanakan Pembelajaran Kelas Ekperimen dan control sama-sama dilaksanakan 3 pertemuan. Untuk mengamati keterlaksanaan guru dalam melaksanakan sintak pembelajaran disusun lembar observasi. Lembar observasi mengajar guru kelompok ekperimen dibagi menjadi tiga tahap yaitu kegiatan awal, kegiatan inti dan penutup. Ketelaksanaan sintak pembelajaran pendekatan saintifik melalui model Discovey Learning dapat diketahui bahwa pada pertemuan I ada 1 item pengamatan yang tidak dilaksanakan oleh guru. Pada saat kegiatan penutup guru tidak melakukan tindak lanjut. Sedangkan 16 item sudah telaksana semua. Pada pertemuan II ada 1 item pengamatan yang tidak dilaksanakan oleh guru. Pada saat kegiatan penutup guru tidak melakukan tindak lanjut seperti pada pertemuan I. Sedangkan pada pertemuan III semua item terlaksana semua.

Pelaksanaan pada kelas kontrol dilaksanaka menggunakan model $P B L$. Lembar observasi mengajar guru kelompok kontrol dibagi menjadi tiga tahap yaitu kegiatan awal, kegiatan inti dan penutup. Keterlaksanaan sintak pembelajaran PBL dapat diketahui bahwa pada pertemuan I ada 3 item yang tidak dialaksanakan oleh guru pada kegiatan investigasi kelompok, analisis hasil dan tindak lanjut, sedangkan 16 item terlaksana semua. Pada pertemuan II ada 1 item tidak terlaksana oleh guru pada kegiatan penutup tidak melaksanakan tindak lanjut. Sedangkan pada pertemuan III semua item terlaksana semua.

Pengolahan data hasil belajar kelompok ekperimen dilakukan melalui perhitungan dalam mencari range, banyaknya kategori, dan interval untuk membuat tabel destribusi frekuensi. Berikut disajikan Tabel 1 destribusi frekuensi hasil belajar pretest dan postest kelas ekperimen.

Tabel 1. Hasil Belajar Pretest dan Postest Kelas Eksperimen

\begin{tabular}{cccccc}
\hline & Pretest & & \multicolumn{3}{c}{ Postest } \\
\hline Interval & frekuensi & persentase & Interval & frekuensi & persentase \\
\hline $\mathbf{5 2}-\mathbf{5 8}$ & 3 & $13,64 \%$ & $\mathbf{7 0 - 7 5}$ & 1 & $4,55 \%$ \\
$\mathbf{5 9}-\mathbf{6 5}$ & 4 & $18,18 \%$ & $\mathbf{7 6 - \mathbf { 8 1 }}$ & 6 & $27,27 \%$ \\
$\mathbf{6 6}-\mathbf{7 2}$ & 8 & $36,36 \%$ & $\mathbf{8 2}-\mathbf{8 7}$ & 1 & $4,55 \%$ \\
$\mathbf{7 3}-\mathbf{7 9}$ & 3 & $13,64 \%$ & $\mathbf{8 8}-\mathbf{9 3}$ & 7 & $31,82 \%$ \\
$\mathbf{8 0}-\mathbf{8 6}$ & 3 & $13,64 \%$ & $\mathbf{x}>\mathbf{9 4}$ & 7 & $31,82 \%$ \\
$\mathbf{8 7}-\mathbf{9 3}$ & 1 & $4,55 \%$ & & & \\
Jumlah & 22 & $100,00 \%$ & Jumlah & 22 & $100,00 \%$ \\
\hline
\end{tabular}

Dari Tabel 1 dapat diketahui pada kelas eksperimen hasil pretest, siswa yang mendapat skor hasil 52 sampai 58 sebanyak 3 anak dengan persentase 13,64\%. Siswa yang mendapat skor hasil 59 sampai 65 sebanyak 4 anak dengan persentase $18,18 \%$. Siswa yang mendapat sko hasil 66 sampai 72 sebanyak 8 anak dengan persentase $36,36 \%$. Siswa yang mendapat skor hasil 73 sampai 79 sebanyak 3 anak dengan persentase $13,64 \%$. Siswa yang mendapat skor hasil 80 sampai 86 sebanyak 3 anak dengan persentase $13,64 \%$. Dan siswa yang mendapat nilai 87 sampai 93 sebanyak 1 anak dengan persentase 4,55\%. Sedangkan hasil posttest, siswa yang mendapat skor hasil 70 sampai 75 terdi dari 1 anak dengan persentase 4,55\%. Siswa yang mendapat skor hasil 76 sampai 81 sebanyak 6 anak dengan persentase $27,27 \%$. Siswa yang mendapat skor hasil 82 sampai 87 sebanyak 1 anak dengan persentase $4,55 \%$. Siswa yang mendapat skor hasil 88 sampai 93 sebanyak 7 anak dengan persentase $31,82 \%$. Dan siswa yang mendapat nilai lebih dari 94 sebanyak 7 anak dengan persentase $31,82 \%$.

Berikut disajikan Tabel 2 destribusi frekuensi hasil belajar pretest dan posttest kelas kontrol. 
Tabel 2. Hasil belajar Kognitif Pretest dan Posttest Kelas Kontrol

\begin{tabular}{cccccc}
\hline & Pretest & & \multicolumn{3}{c}{ Postest } \\
\hline Interval & frekuensi & persentase & Interval & frekuensi & persentase \\
\hline $\mathbf{5 6}-\mathbf{6 0}$ & 2 & $8,00 \%$ & $\mathbf{7 0 - 7 5}$ & 6 & $24,00 \%$ \\
$\mathbf{6 1}-\mathbf{6 5}$ & 4 & $16,00 \%$ & $\mathbf{7 6 - 8 1}$ & 10 & $40,00 \%$ \\
$\mathbf{6 6}-\mathbf{7 0}$ & 4 & $16,00 \%$ & $\mathbf{8 2}-\mathbf{8 7}$ & 2 & $8,00 \%$ \\
$\mathbf{7 1}-\mathbf{7 5}$ & 10 & $40,00 \%$ & $\mathbf{8 8 - 9 3}$ & 5 & $20,00 \%$ \\
$\mathbf{7 6}-\mathbf{8 0}$ & 4 & $16,00 \%$ & $\mathbf{X}>\mathbf{9 4}$ & 2 & $8,00 \%$ \\
$\mathbf{8 1}-\mathbf{8 5}$ & 1 & $4,00 \%$ & & & \\
Jumlah & 25 & $100,00 \%$ & Jumlah & 25 & $100,00 \%$ \\
\hline
\end{tabular}

Dari Tabel 2 dapat diketahui pada kelas kontrol hasil pretest, siswa yang mendapat skor hasil 56 sampai 60 terdiru dari 2 anak dengan persentase 8,00\%. Siswa yang mendapat skor hasil 61 sampai 65 sebanyak 4 anak dengan persentase $16,00 \%$. Siswa yang mendapat sko hasil 66 sampai 70 sebanyak 4 anak dengan persentase $16,00 \%$. Siswa yang mendapat skor hasil 71 sampai 75 sebanyak 10 anak dengan persentase $40,00 \%$. Siswa yang mendapat skor hasil 76 sampai 80 sebanyak 4 anak dengan persentase $16,00 \%$. Dan siswa yang mendapat nilai 81 sampai 85 sebanyak 1 anak dengan persentase $4,00 \%$. Sedangkan I hasil posttest, siswa yang mendapat skor hasil 70 sampai 75 terdiri dari 6 anak dengan persentase 24,00\%. Siswa yang mendapat skor hasil belajar 76 sampai 81 sebanyak 10 anak dengan persentase $40,00 \%$. Siswa yang mendapat skor hasil 82 sampai 87 sebanyak 2 anak dengan persentase $8,00 \%$. Siswa yang mendapat skor hasil 88 sampai 93 sebanyak 5 anak dengan persentase $20,00 \%$. Dan siswa yang mendapat nilai $x>94$ sebanyak 2 anak dengan persentase $8,00 \%$.

Uji normalitas data digunakan untuk mengetahui apakah penyebaran data pada kelas eksperimen dan kelas kontrol berdistribusi normal atau tidak. Uji normalitas dalam penelitian ini menggunakan teknik Shapiro-Wilk. Perhitungan dilakukan dengan menggunakan SPSS 17.0 for window. Hasil uji normalitas penyebaran data dengan teknik Shapiro-Wilk, tingkat signifikan asyiomotorik dua sisi dengan taraf kepercayaan 5\% (Asyimp. Sig. 2-tailed). $H_{1}$ diterima apabila $\mathrm{P}>0,05$ dan $H_{0}$ ditolak. Sedangkan, jika $\mathrm{P}<0,05 H_{1}$ ditolak dan $H_{0}$ diterima. Dan Uji homogenitas dalam penelitian ini, pada dasarnya dilakukan untuk membuktikan bahwa data yang akan dianalisis memiliki variansi yang sama. Hasil uji homogenitas hasil belajar pretest dapat dilihat melalui Test of Homogeneity of Variances menunjukkan nilai Sig. 0,848 >0,05. Hal tersebut mengindikasikan bahwa varian antara kelas eksperimen dan kelas kontrol adalah sama. Sedangkan hasil uji homogenitas hasil belajar posttest menunjukkan nilai Sig. $0,148>0,05$. Hal tersebut mengindikasikan bahwa varian antara kelas eksperimen dan kelas kontrol adalah sama.

Berdasarkan uji normalitas dan homogenitas yang telah dilakukan diketahui bahwa skor dan hasil belajar berdistribusi normal dan homogen maka langkah selanjutnya dilakukan analisis uji t. Uji t dalam penelitian ini digunakan untuk mengetahui ada tidaknya perbedaan rata-rata hasil belajar antara dua kelompok kelas yang tidak berhubugan. Berdasarkan hasil perhitungan diketahui t sebesar 2,672 dengan nilai signifikansinya pada kolom Sig (2-tailed) sebesar 0,01. Nilai t hitung positif ( nilai kelas ekperimen lebih tinggi dari kelas kontrol). Perbedaan rata-rata dari kedua kelas (mean difference) sebesar 6,8472 yang merupakan selisih kedua kelas eksperimen dengan kelas kontrol. Dengan demikian analisis pada uji beda ini dinyatakan bahwa ada perbedaan rata-rata dari kelas ekperimen dan kelas kontrol. 
Dari hasil penelitian ini dapat dilihat keberhasilan guru dalam melaksanakan treatment pada kelas ekperimen menggunakan pendekatan saintifik melalui model Discovery Learning dalam pembelajaran IPA. Hal ini dapat dilihat dari skor hasil belajar yang didapatkan dari kelas ekperimen dan kelas kontrol. Dan dari uji yang dialkukan menyatakan bahwa terdapat perbedaan pengaruh yang signifikan antara pembelajaran pendekatan saintifik melalui model Discovery Learning dengan model pembelajaran $P B L$ terhadap hasil belajar IPA pada siswa kelas 3 Sekolah Dasar. Hasil penelitian yang dilakukan sejalan dengan beberapa penelitian yang telah dilakukan sebelumnya. oleh Lisa Saputri bahwa adanya perbedaan pengaruhyang signifikan hasil belajar IPA dengan Penggunaan Metode Discovery.

\section{SIMPULAN}

Berdasarkan hasil penelitian dan analisis data yang telah dibahas pada bab sebelumnya, maka dapat disimpulkan bahwa terdapat perbedaan pengaruh dengan yang signifikan antara pembelajaran pendekatan saintifik melalui model Discovery Learning dengan model Problem Based Learning terhadap hasil belajar IPA siswa kelas 3 Sekolah Dasar. Hal tersebut dapat dilihat dari analisis mennggunakan uji Independent Sample T-Test. Dari hasil uji Independent Sample T-Test kolom Equal variance assumed diperoleh bahwa skor koefisien t hitung sebesar 2,672 dengan nilai signifikansinya pada kolom Sig (2-tailed) sebesar 0,01. Sedangkan dalam penelitian ini, untuk perolehan rata-rata hasil belajar kelas ekperimen sebesar 87,7273 dan untuk kelas kontrol sebesar 80,88 dengan perbedaan rata-rata hasil belajaranya adalah 6,8472 . Hal tersebut menunjukan bahwa pembelajaran dengan pendekatan saintifik melalui model Discovery Learning lebih efektif daripada pembelajaran dengan model Problem Based Learning.

\section{DAFTAR PUSTAKA}

Affandi, Amk. (2014). Pembelajaran Melalui Pendekatan Saintifik. Diakses dari http://kompasiana.com/pembelajaran-melalui-pendekatan-saintifik-687381

Daryanto. (2014). Pendekatan Pembelajaran Saintifik Kurikulum 2013. Yogyakarta: Gava Media

Fauzan, D.A. (2014). Pendidikan Kurikulum 2013. http://kompasiana.com/artikelpendidikan-kurikulum-2013-679257

Herriati. (2014). Model Pembelajaran Discovery Learning Kurikulum 2013. http://kompasiana.com/artikel-model-pembelajaran-671463

Kurikulum dan Pertimbangan yang Tak Terungkap. (2014). Kompas.com. http://Kurikulum.dan.Pertimbangan.yang.Tak.Terungkap

Menteri Pendidikan dan Kebudayaan RI. (2014). Peraturan Mentri Pendidikan dan Kebudayaan RI tentang KTSP Pada Pendidikan Dasar dan Menengah (Permendikbud Nomor 61 tahun 2014). Jakarta: Penulis.

Menteri Pendidikan dan Kebudayaan RI. (2014). Peraturan Mentri Pendidikan dan Kebudayaan RI tentang Standar Proses Pada Pendidikan Dasar dan Menengah (Permendikbud Nomor 65 tahun 2013). Jakarta: Penulis.

Sani, A.R. (2014). Pembelajaran Saintifik Untuk Implementasi Kurikulum 2013. Jakarta: PT. Bumi Aksara

Saputri, L. (2012). Pengaruh Penggunaan Metode Discovery Pada Pelajaran IPA Pokok Bahasan Bunyi Terhadap Hasil Belajar Siswa Kelas IV SD Kristen Satya Wacana Salatiga Semester II Tahun Pelajaran 2011/2012. Skripsi.Salatiga: Universitas Kristen Satya Wacana Salatiga. http://repository.uksw.edu.

Sugiyono. (2013). Metode Penelitian Pendidikan: Pendekatan Kuantitatif, kualitatif, dan R\&D. Bandung : Alfabeta 